\title{
Efficacy of Biocontrol Agents against Drechslera setariae Causing Leaf Spot of Pearl Millet
}

\author{
Rajendra Nasnwa ${ }^{1}$, S.L. Godara ${ }^{1}$ and Manjeet Singh $^{2^{*}}$ \\ ${ }^{I}$ Department of Plant Pathology, SKRAU, Bikaner, Rajasthan, India \\ ${ }^{2}$ Department of Plant Pathology, CCS Haryana Agricultural University, Hisar, \\ Haryana, India \\ *Corresponding author
}

\section{A B S T R A C T}

\begin{tabular}{|c|}
\hline Keywords \\
\hline $\begin{array}{l}\text { Pearl millet, Leaf spot, } \\
\text { Drechslera setariae, } \\
\text { Biocontrol, Antifungal }\end{array}$ \\
\hline Article Info \\
\hline $\begin{array}{l}\text { Accepted: } \\
10 \text { April } 2018 \\
\text { Available Online: } \\
10 \text { May } 2018\end{array}$ \\
\hline
\end{tabular}

\section{Introduction}

Pearl millet (Pennisetum glaucum L.) locally known as bajra, combo, sajja, bari, ganti or kambam, is an allogamous crop having protogynous nature, It belongs to family in Poaceae. It is also called as a poor man's food grain, grown as a nutrient rich food source for human consumption as well as a fodder / forage crop in Asia and Africa. The pearl millet grains are very good nutritious and form the staple food or diet of approximately $10 \%$ population in India. It is a good source of high quality protein with superior amino acid profile (11.5\%), carbohydrate (59.8-78.2\%), fat $(4.1-6.4 \%)$ and rich in good amount of minerals particularly iron and phosphorus. India is the largest producer of pearl millet, both in terms of area (7.0 million hectares) and production (9.25 million tonnes), with an average productivity of $1250 \mathrm{~kg} / \mathrm{ha}$ (Anonymous, 2014-15a).

Pearl millet is mainly grown in Rajasthan, Maharashtra, Gujarat, Uttar Pradesh, Haryana, Karnataka, Madhya Pradesh, Tamil nadu and Andhra Pradesh states of the country. Rajasthan is the highest producing state in India, it is cultivated on 40.76 lac hectare area with production 44.56 lac tonne and productivity $1093 \mathrm{~kg} / \mathrm{ha}$ (Anonymous, 201415b). Major pearl millet producing districts of Rajasthan are Bikaner, Barmer, Jhunjhunu, 
Jaisalmer, Churu, Jaipur, Alwar, Karoli, Dholpur, Swai Madhopur, and Bharatpur.

Pearl millet encounters number of diseases which attack the crop during its growth, cause yield and economic loss. Among several diseases of pearl millet, Leaf spot disease (Drechslera setariae) a major problem and comes every year in almost all the pearl millet growing regions including Rajasthan. The disease is characterized by the presence lesions with dark margins and ash coloured centers of varying in size and sometimes blight the leaves completely. Drechslera setariae was isolated from the rotted seeds and infected parts of seedlings. The seed used was obtained from Mysore (Karnataka), India and was found to be infected with $D$. setariae, which has been reported from the United States as seed borne in pearl millet, causing seed rot, blight and leaf spot (Wells and Winstead, 1965; Wells and Burton, 1967). The disease has also been noticed in India by Bhowmik (1972) and Balasubramanian (1980). Use of bio control agents is ecofriendly approach, ecologically safe, ideal, cheap and long lasting method of plant disease management (Butt and Copping, 2000). The aim of the present study was to investigate the bio efficacy of different bio control agents against Drechslera setariae causing leaf spot of pearl millet.

\section{Materials and Methods}

The bio control agents viz., Trichoderma harzianum, Trichoderma viride, Pseudomonas fluorescens and Bacillus subtilis were evaluated under in vitro conditions for their antagonistic effect against Drechslera setariae by dual culture technique using potato dextrose agar medium (Mortan and Straube, 1955). $20 \mathrm{ml}$ of sterilized and cooled potato dextrose agar (PDA) medium was poured into sterile petri plates and allowed to solidify.

A five mm disk of test fungus (Drechslera setariae) and fungal bio control/ antagonists agents were placed exactly opposite to each other on the petri plate by leaving five $\mathrm{mm}$ from periphery. In case of evaluation of bacterial biocontrol agents, one disc of medium with bacterium ( $5 \mathrm{~mm}$ diameter) was taken and put into a test tube containing $10 \mathrm{ml}$ of sterilized water and shaken for 10 minutes. The bacterial isolates were streaked at periphery of petri plates plated with PDA medium and mycelial disc (5mm diameter) of fresh culture of Drechslera setariae was placed on the other side of Petri plate. All the petriplates were incubated in a BOD incubator at $27 \pm 1{ }^{0} \mathrm{C}$ for 10 days. Petri dishes inoculated with test fungal discs alone served as control.

Four replications were maintained for each isolate in a completely randomized design. After, control petriplate reached growth of 90 $\mathrm{mm}$ in diameter, the radial growth of pathogen was measured. Observations on width of inhibition zone and mycelial growth of test pathogen were recorded and per cent inhibition of pathogen growth was calculated by using the formula described by Vincent (1947).

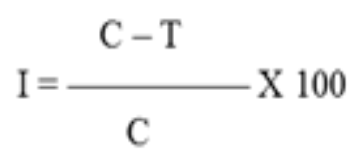

Where,

$\mathrm{I}=$ Per cent inhibition

$\mathrm{C}=$ Growth in control

$\mathrm{T}=$ Growth in treatment

\section{Results and Discussion}

The comparative antifungal activities of four biocontrol agents were assessed against Drechslera setariae. The results presented in Table 1 and figure 1 revealed that growth of 
the $D$. setariae was significantly checked as compared to control by the antagonistic effect of all the biocontrol agents tested. The biocontrol agents also restricted the growth of D. setariae and did not allow it to grow further.

The least growth of the D. setariae was observed in Trichoderma viride $(25.00 \mathrm{~mm})$ followed by Trichoderma harzianum (29.13 $\mathrm{mm})$, Pseudomonas fluorescens (36.50 $\mathrm{mm})$ and Bacillus subtilis $(49.25 \mathrm{~mm})$ as compared in control where it was $90.00 \mathrm{~mm}$ growth
(Table 1 and Fig. 1).

The per cent inhibition of mycelial growth was recorded in Trichoderma viride (72.22\%) that was significantly superior to $T$. harzianum (67.64 \%) and P. fluorescens (59.44\%). However, Bacillus subtilis (45.28 \%) was found to be least inhibitory (Table 1 and Fig. 1). Not much work has been done on bio control agents or antagonists against leaf spot pathogen (Drechslera setariae) of Pearl millets.

Table.1 Effect of different bio control agents against inhibition of mycelial growth of

\section{Drechslera setariae}

\begin{tabular}{|c|c|c|c|}
\hline Sr. No. & Bio control agent & Mycelial growth (mm) & Growth inhibition (\%) \\
\hline 1 & Trichoderma harzianum & $29.13^{*}$ & $67.64^{*}(55.31)^{* *}$ \\
\hline 2 & Trichoderma viride & 25.00 & $72.22(58.18)$ \\
\hline 3 & Pseudomonas fluorescens & 36.50 & $59.44(50.42)$ \\
\hline 4 & Bacillus subtilis & 49.25 & $45.28(42.27)$ \\
\hline 5 & Control & 90.00 & - \\
\hline \multicolumn{2}{|c|}{$\mathrm{CD}(\mathrm{P}=0.05)$} & 1.63 & $(1.79)$ \\
\hline \multicolumn{2}{|c|}{ C.V. } & 2.49 & 2.84 \\
\hline
\end{tabular}

*Average of four replications

**Data in parentheses are angular transformation.

Fig.1 Effect of different bio control agents against inhibition of mycelial growth of Drechslera setariae

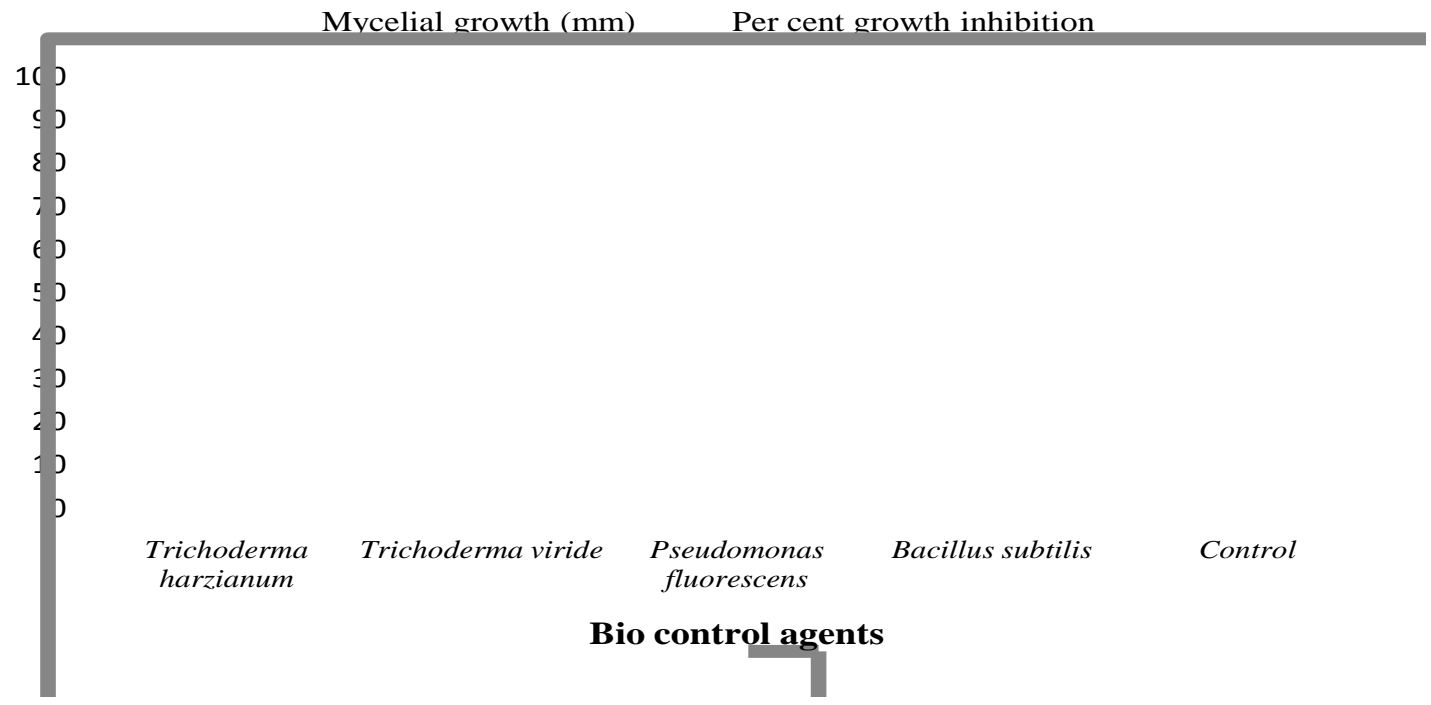


Present finding has close concurrence with the finding of Hulagappa (2012) and Kumar et al., (2009) against Drechslera / Helminthosporium maydis. Elamathi et al., 2016 also recorded the Trichoderma viride as control agent of the brown leaf spot pathogen (Bipolaris oryzae) followed by T. harzianum.

Khalili et al., (2012) also reported that the in vitro antagonism tests revealed that Trichoderma sp. significantly inhibited the mycelial growth of Bipolaris oryzae. The effective antagonistic activity of Trichoderma sp. against Bipolaris oryzae was confirmed by the earlier workers (Jha et al., 2004; Harish et al., 2007; Abdel-Fataah et al., 2007 and Franca et al., 2015). Trichoderma harzianum and Pseudomonas fluorescens were found effective against brown leaf spot disease of paddy caused by Drechslera oryzae (Rao et al., 2013). Pseudomonas fluorescens strains were found most effective with the highest antagonistic activity against three fungal pathogens viz., F. moniliforme, $R$. solani and A. alternate (Maurya et al., 2014). The antagonistic nature of Bacillus subtilis, reduced the mycelial growth of Helminthosporium maydis (Muhammad and Amusa 2003; Khamari and Beura, 2014).

Further, it can be concluded that among the biocontrol agents, Trichoderma viride found most effective antagonist against $D$. setariae followed by $T$. harzianum and $P$. fluorescens. Whereas, B. subtilis was found to be least effective. All the antagonists significantly checked the growth of $D$. setariae either by over growing or by exhibiting inhibition zones. Both the species of Trichoderma showed considerable antimycotic activity by checking the radial growth of $D$. setariae. However, the bacterial bio control agents viz., Pseudomonas fluorescens and Bacillus subtilis proved least effective and cause less mycelial growth inhibition of the test fungus as compare to fungal antagonists.

\section{References}

Abdel-Fataah, G.M., Shabana, Y.M., Ismail, A.E. and Rashad, Y.M., 2007. Trichoderma harzianum: a biocontrol agent against Bipolaris oryzae. Mycopathol. 164, 81-99.

Anonymous, 2014-2015a. Ministry of Agriculture, Govt. of India.

Anonymous, 2014-2015b. Department of Agriculture, Govt. of Rajasthan.

Balasubramanian, K. A. 1980. Association of Drechslera setariae with downy mildew affected pearl millet. Curr. Sci. 49 (6): 233-234.

Bhowmik, T. P. 1972. Bipolaris setariae on two new host in India. Indian Phytopathol. 25: 590-591.

Butt, T.M. and Copping, L.G. 2000. Fungal biological control agents. Pesticide Outlook, pp. 186-191.

Elamathi, P., Madhanraj, P. Panneerselvam, A. and Prabakaran, P., 2017. Antagonistic Activity of Potential Soil Fungi against Bipolaris oryzae (Breda de Haan). International Journal of Current Microbiology and Applied Sciences, 6(1): 750-754.

França, S.K.S., Cardoso, A.F., Lustosa, D.C., Corsi de Filippi, M.C., Silva G.B. and Soares Ramos, E.M.L. 2015. Biocontrol of sheath blight by Trichoderma asperellum in tropical lowland rice. Sustain. Dev; 35:317-324.

Harish, S., Saravavakumar, D., Radjacommar, R., Ebenezar, E.G. and Seetharaman, K., 2007. Use of plant extracts and biocontrol agents for the management of brown spot disease in rice. Biocontrol, 53(3): 555-567.

Hulagappa, 2012. Studies on maydis leaf blight of maize caused by Drechslera maydis (Nisikado) Subram and Jain, M.Sc. thesis UAS, Dharwad, pp.52-62

Jha, M. M., Kumar, S. and Haasan, S. 2004. Response of bioagents against maydis 
leaf blight of maize. Annals of Biology, 20: 177-179.

Khalili, E., Sadravi, M., Naeimi, S. and Vahid Khosravi. 2012: Biological control of rice brown spot with native isolates of three Trichoderma Species Brazilian Journal of Microbiology: 297-305

Khamari, B. and Beura, S.K. 2014. Efficacy of bio control agents against maydis leaf blight of maize. Journal of Plant Protection and Environment, 11(2): 9597.

Kumar, S., Rani, A. and Jha, M.M. 2009c. Potential of Trichoderma spp. as biocontrol agents against pathogens causing maydis leaf blight of maize. Journal of Biological Control, 23(1): 89-91.

Maurya, M.K., Singh, R. and Tomer, A., 2014. In vitro evaluation of antagonistic activity of Pseudomonas fluorescens against fungal pathogen. JBiopest, 7(1): 43-46.

Morton, D. J. and Straube, W. H. 1955. Antagonistic and stimulatory effect of microorganisms upon Sclerotium rolfsii. Phytopathology, 45: 417- 420.

Muhammad, S. and Amusa, N.A., 2003. In vitro inhibition of growth of some seedling blight inducing pathogens by composte inhibiting microbes. African Journal of Biotechnology, 2(6): 161164.

Rao Y, Lal, A.A., Simon, S., Singh, L., 2013. Management of brown spot (Drechslera oryzae) of Rice. Annals of Plant Protection Science, 21(2): 450-452.

Vincent, J.M. 1947. Distortion of fungal hyphae in the presence of certain inhibitors. Nature. 159: 850.

Wells, H. D. and Burton, G. W. 1967. Helminthosporium setariae on pearl millet, Pennisetum typhoides, as affected by age of host differences. Crop Sci. 7: 621-622.

Wells, H. D. and Winstead, E. E. 1965. Seed borne fungi in Georgia grown and western grown pearl millet seed on safe in Georgia during 1960. Pl. Dis. Rep. 49: 487-489.

\section{How to cite this article:}

Rajendra Nasnwa, S.L. Godara and Manjeet Singh. 2018. Efficacy of Biocontrol Agents against Drechslera setariae Causing Leaf Spot of Pearl Millet. Int.J.Curr.Microbiol.App.Sci. 7(05): 1035-1039. doi: https://doi.org/10.20546/ijcmas.2018.705.128 